\title{
Aggregation Study of $\mathrm{Ag}-\mathrm{TiO}_{2}$ Composites
}

\author{
María Eugenia Noriega-Treviño, $0^{1,2}$, Claudia Cristina Quintero-González ${ }^{1}$, \\ José Elpidio Morales-Sánchez ${ }^{1,2,3}$, Jesús María Guajardo-Pacheco ${ }^{1,2,3}$, \\ Martha Eugenia Compeán-Jasso ${ }^{1}$, Facundo Ruiz ${ }^{4}$
}

\begin{abstract}
${ }^{1}$ Science Faculty, Universidad Autónoma de San Luis Potosí, San Luis Potosí, México; ${ }^{2}$ Mathematics and Physics Department, Universidad Autónoma de San Luis Potosí, San Luis Potosí, México; ${ }^{3}$ Materials Advanced Research Center, Chihuahua, México; ${ }^{4}$ Materials Advanced Research Center, Apodaca, México.

E-mail: ${ }^{*}$ marunor@uaslp.mx
\end{abstract}

Received October 21 $1^{\text {st }}, 2011$; revised November $30^{\text {th }}, 2011$; accepted December $7^{\text {th }}, 2011$.

\begin{abstract}
Most of the toxicity data presented in the literature are obtained in relatively simple media, like distilled water. The literature reported that nanoparticles agglomerate immediately upon being added to cell culture media and if the agglomerates are used directly in antimicrobial studies, the interpretation of the toxicity results tends to be complicated. Six different molar ratios $\mathrm{Ag}-\mathrm{TiO}_{2}$ composites were synthesized by a reduction method using two different commercial $\mathrm{TiO}_{2}$ particles as base materials and were used to find the aggregate size in distilled water and Mueller-Hinton Broth, and to obtain the minimum inhibitory concentrations (MIC) against E. coli and E. faecalis. To evaluate the evolution of the $\mathrm{Ag}-\mathrm{TiO}_{2}$ particle size (z-average) three dilutions of each of the synthesized composites $100 \mu \mathrm{g} / \mathrm{ml}, 250 \mu \mathrm{g} / \mathrm{mL}$ and $500 \mu \mathrm{g} / \mathrm{ml}$ were realized in deionized water and Mueller Hinton broth. It was found that $\mathrm{Ag}-\mathrm{TiO}_{2}$ composites increased in size after being diluted in Mueller-Hinton Broth, but once they grew in size, they remained constant for 24 minutes, and after this time, did not affect the MIC for the microorganisms involved.
\end{abstract}

Keywords: $\mathrm{Ag}_{-} \mathrm{TiO}_{2}$, Composites, Nanoparticles, Particles, Aggregate Size, MIC

\section{Introduction}

The most common method of producing silver nanoparticles is a chemical reduction of silver salt dissolved in water with a reducing compound $[1,2]$. Silver nanomaterials exhibit broad-spectrum biocidal activity toward bacteria, fungi, viruses and algae [3].

Several factors have been reported to influence silver nanoparticle toxicity like particle size, shape, $\mathrm{pH}$, ionic strength and the presence of divalent cations and macromolecules [4-8]. The stability of silver nanoparticles also influences toxicity since the formation of aggregates tends to decrease biocidal activity $[9,10]$. Most of the toxicity data presented in the literature are obtained in relatively simple media like distilled water.

It was found that $\mathrm{TiO}_{2}$, when irradiated with UV radiation, acted as an antimicrobial [11]. It had been reported that photocatalytic and antimicrobial properties of $\mathrm{TiO}_{2}$ can be improved by growing particles of a noble metal like $\mathrm{Ag}, \mathrm{Au}$ or $\mathrm{Cu}$ over its surface or inside a matrix [12-14]. Composites of silver coatings over titanium dioxide nanoparticles are used in products to produce antibacterial activity [15].

The literature reported that nanoparticles agglomerate immediately upon being added to cell culture media and if the agglomerates are used directly in antimicrobial studies, the interpretation of the toxicity results tends to be complicated. Agglomerates of nanoparticles have been shown to exert lower antibacterial effects as compared to well dispersed nanoparticles [16]. It was reported that the presence of proteins within the nanoparticle solution can stabilize the silver nanoparticles against aggregation [1619].

It was the purpose of this study to evaluate the aggregate size of $\mathrm{Ag}-\mathrm{TiO}_{2}$ composites in deionized water and Mueller Hinton Broth, and analyze the bactericidal activity of the composites using two bacterial strains.

\section{Materials and Methods}

\subsection{Materials}

Two commercial $\mathrm{TiO}_{2}$ particles were used as a base materials, Degussa P25 and DuPont ${ }^{\mathrm{TM}}$ Ti-Pure R-902, $\mathrm{AgNO}_{3}$ (Sigma Aldrich, ACS reagent) was used as a precursor, $\mathrm{NaBH}_{4}$ (Sigma Aldrich, ACS reagent) were used as a reducing agent and $\mathrm{NH}_{4} \mathrm{OH}(30 \% \mathrm{w} / \mathrm{w}$ aqueous solution, Sigma Aldrich, ACS reagent), were used to adjust de $\mathrm{pH}$. 


\subsection{Synthesis of the Composites}

Silver nanoparticles were synthesized over the surface of two different commercial $\mathrm{TiO}_{2}$ particles. The composites with three molar ratios were prepared following a method reported by Nino-Martinez et al. and they demostrated that the nature of de nanoparticles is elemental silver [12].

All preparations started as follows: $0.2 \mathrm{~g}$ of $\mathrm{TiO}_{2}$ particles were dispersed in $100 \mathrm{~mL}$ of deionized water by ultrasound for five minutes. Afterwards the 1:10, 1:25 and 1:50 molar ratios $\mathrm{Ag}-\mathrm{TiO}_{2}$ composites were obtained by addition of $0.0425 \mathrm{~g}, 0.0169 \mathrm{~g}, 0.00845 \mathrm{~g}$ of $\mathrm{AgNO}_{3}$ respectively. The solution was magnetically stirred for 30 min at $\mathrm{pH} \mathrm{7,} \mathrm{then} \mathrm{predetermined} \mathrm{amount} \mathrm{of} \mathrm{NaBH}_{4}$, previously dissolved in deionized water, was added. The $\mathrm{pH}$ of the reaction was adjusted to 10 by adding $\mathrm{NH}_{4} \mathrm{OH}$, and magnetically stirred for another $30 \mathrm{~min}$.

\subsection{Characterization}

The composites obtained were characterized by using Dynamic Light Scattering in a Malvern Zetasizer Nano Zs. Transmission electron microscopy (TEM) analysis were performed on a JEOL JEM-1230 at an accelerating voltage of $100 \mathrm{kV}$.

\subsection{Bacterial Strains}

Two bacteria were evaluated, Escherichia coli (ATCC 25922) Gram-negative and Enterococcus faecalis, (ATCC 29212) Gram-positive.

\subsection{Antibacterial Test}

The applied antibacterial test was the standard microdilution method (NCCLS-CLSI N7 A7 Vol. 26 No. 2, 1996), which determines the minimum inhibitory concentration
(MIC, as the minimum concentration of tested substance that inhibited the growth of the bacterial strain). The MIC was determined on 96-well microdilution plates. Microorganisms $\left(10^{5} \mathrm{CFU} / \mathrm{mL}\right)$ were exposed to serial dilutions of $\mathrm{Ag}-\mathrm{TiO}_{2}$ particles with Mueller-Hinton Broth (Fluka), and the endpoints were determined when no turbidity in the well was observed after 24 hours of incubation at $37^{\circ} \mathrm{C}$. All assays were carried out in triplicate and the $\mathrm{Ag}-\mathrm{TiO}_{2}$ composites were used in the form in which they had been prepared.

\section{Results and Discussion}

\subsection{Characterization}

Six different samples were synthesized with $\mathrm{Ag}-\mathrm{TiO}_{2}$ molar ratios $1: 10,1: 25$ and 1:50, three with $\mathrm{TiO}_{2} \mathrm{P} 25$, and three with $\mathrm{TiO}_{2}$ R-902 as base materials.

TEM images shows that $\mathrm{TiO}_{2} \mathrm{P}-25$ had a size between 10 - $70 \mathrm{~nm}, \mathrm{TiO}_{2}$ DuPont R902 had a size $200-300 \mathrm{~nm}$. The Ag nanoparticles deposited on $\mathrm{TiO}_{2} \mathrm{P} 25$ surface had a size between 5 to $40 \mathrm{~nm}$, and Ag nanoparticles deposited in $\mathrm{TiO}_{2} \mathrm{R} 902$ surface had a size between 5 to $50 \mathrm{~nm}$. Figures 1(a) and (b) shows the TEM images for 1:10 Ag- $\mathrm{TiO}_{2} \mathrm{R} 902$ and 1:50 Ag- $\mathrm{TiO}_{2} \mathrm{R} 902$ composites. Figures 1(c) and (d) shows the TEM images for 1:10 Ag- $\mathrm{TiO}_{2} \mathrm{P} 25$ and 1:50 Ag- $\mathrm{TiO}_{2}$ P25 composites.

In DLS analyses, $\mathrm{Ag}-\mathrm{TiO}_{2}$ composites present an overall particle diameter (z-average) 377.5, 288, 282, 254.6, 252.4 and $251.5 \mathrm{~nm}$, for samples $\mathrm{Ag}-\mathrm{TiO}_{2} \mathrm{R} 902$ 1:10, Ag- $\mathrm{TiO}_{2}$ R902 1:25 Ag-TiO 2 R902 1:50, Ag-TiO 2 P25 1:10, Ag- $\mathrm{TiO}_{2}$ P25 1:25, Ag- $-\mathrm{TiO}_{2}$ P25 1:50 respectively. The polydispersity index (PDI) was below 0.3 in all cases.

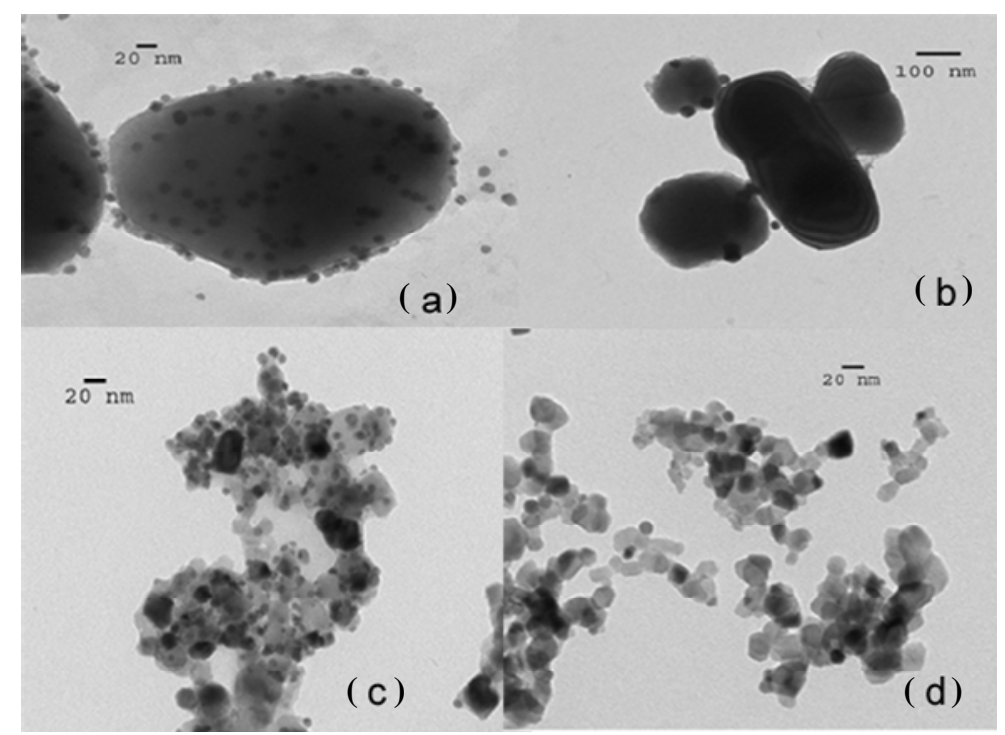


${\mathrm{Ag}-\mathrm{TiO}_{2}}_{2} \mathrm{P} 25$. 
The zeta potential of the same samples were $-58.8 \pm$ $6.92,-47.8 \pm 6.03,-46.78 \pm 5.9,-37.7 .8 \pm 4.8,-49.8 \pm$ 5.89 and $-58.8 \pm 6.92$. Figures 2(a) and (b) show the DLS results for 1:10 $\mathrm{Ag}_{-} \mathrm{TiO}_{2} \mathrm{R} 902$ and 1:50 $\mathrm{Ag}-\mathrm{TiO}_{2} \mathrm{R} 902$ composites. Figures 2(c) and (d) show the DLS results for 1:10 Ag- $\mathrm{TiO}_{2} \mathrm{P} 25$ and 1:50 Ag-TiO 2 P25 composites.

Acording to the DVLO Theory, the stability of particle dispersions depends on the balance between attractive and repulsive forces between the particles. With electrostatic stabilization, the zeta potential of the particles provides a repulsive force. In practice if the zeta potential of the particles is higher than $30 \mathrm{mV}$ or lower than $-30 \mathrm{mV}$ the dispersion is stable [19].

To evaluate the evolution of the $\mathrm{Ag}-\mathrm{TiO}_{2}$ particle size (z-average) there were realized three dilutions of each of the six synthesized composites $100 \mu \mathrm{g} / \mathrm{ml}, 250 \mu \mathrm{g} / \mathrm{mL}$ and $500 \mu \mathrm{g} / \mathrm{ml}$ in deionized water and Mueller Hinton broth. It is interesting to note that the particles size remained stable in deionized water for about 24 minutes, 235 - $290 \mathrm{~nm}$ for $\mathrm{Ag}-\mathrm{TiO}_{2} \mathrm{R} 902$ 1:10 (Figure 3(a)), 240 290 for $\mathrm{Ag}-\mathrm{TiO}_{2} \mathrm{R} 902$ 1:25, 257 - $285 \mathrm{~nm}$ for $\mathrm{Ag}-\mathrm{TiO}_{2}$ R902 1:50, 170 - $190 \mathrm{~nm}$ for $\mathrm{Ag}-\mathrm{TiO}_{2}$ P25 1:10, 160 $200 \mathrm{~nm}$ for $\mathrm{Ag}-\mathrm{TiO}_{2}$ P25 1:25 and $190-210 \mathrm{~nm} \mathrm{f}$ $\mathrm{Ag}-\mathrm{TiO}_{2}$ P25 1:50. In contrast the particles became larger in Mueller Hinton Broth but once they grew in size, they remained constant for about 24 minutes, $280-360 \mathrm{~nm}$ for $\mathrm{Ag}-\mathrm{TiO}_{2} \mathrm{R}$ 9021:10 (Figure 3(b)), 260 - $360 \mathrm{~nm}$ for $\mathrm{Ag}-\mathrm{TiO}_{2} \mathrm{R} 902$ 1:25, 260 - $350 \mathrm{~nm}$ for $\mathrm{Ag}-\mathrm{TiO}_{2} \mathrm{R} 902$ 1:50,190 - $215 \mathrm{~nm}$ for $\mathrm{Ag}-\mathrm{TiO}_{2}$ P25 1:10, 180 - $220 \mathrm{~nm}$ for $\mathrm{Ag}-\mathrm{TiO}_{2}$ P25 1:25 and 210 - $240 \mathrm{~nm}$ for $\mathrm{TiO}_{2}$ P25 1:50. The size of de $\mathrm{Ag}-\mathrm{TiO}_{2}$ composites was influenced by the $\mathrm{TiO}_{2}$ base materials in both media.

Steric stabilization is used for nanoparticle dispersion stabilization, where a stabilizer is added to the dispersion and it is adsorbed onto the particle surface, preventing them from coming close to one another [16-19]. It is believed that nanoparticles are covered by proteins immediately upon contact with a cell culture media and physiological environment, resulting in a protein arrangement also referred to as protein corona on the particle surface [16] and this protein corona is exchanging with other nearby proteins [20]. Mueller-Hinton Broth is a complex system containing a lot of different proteins. Therefore, it is possible that $\mathrm{Ag}-\mathrm{TiO}_{2}$ composite adsorb proteins from Mueller-Hinton Broth, as indicated by an increase in the particle size (z-average), which could make them become more stable. The identification of the protein corona composition was not the focus of this work.

\subsection{Antibacterial Results}

Minimum inhibitory concentration values were obtained (Table 1). The six different samples have antibacterial activity. The $\mathrm{TiO}_{2}$ particles present no antibacterial activity. The test was performed on dark and it is reported that $\mathrm{TiO}_{2}$ particles in dark condition present no antibacterial activity $[12,15]$ which is consistent with our results. The six composites show antibacterial activity without light. We evaluated the antibacterial activity after 24 minutes of exposure of the $\mathrm{Ag}-\mathrm{TiO}_{2}$ composites in Mueller-Hinton Broth, and this did not affect the MIC for the microorganisms involved. According to Lynch and coworkers [20] if the protein corona exchanges with other proteins in the medium faster than the time it takes for the particle to attach to the bacteria surface, then the particle-bacteria interactions will not be greatly affected by the presence of the corona. Therefore the MIC of the composite would not be affected. We found the best results in $\mathrm{Ag}-\mathrm{TiO}_{2}$ 1:10 composite.
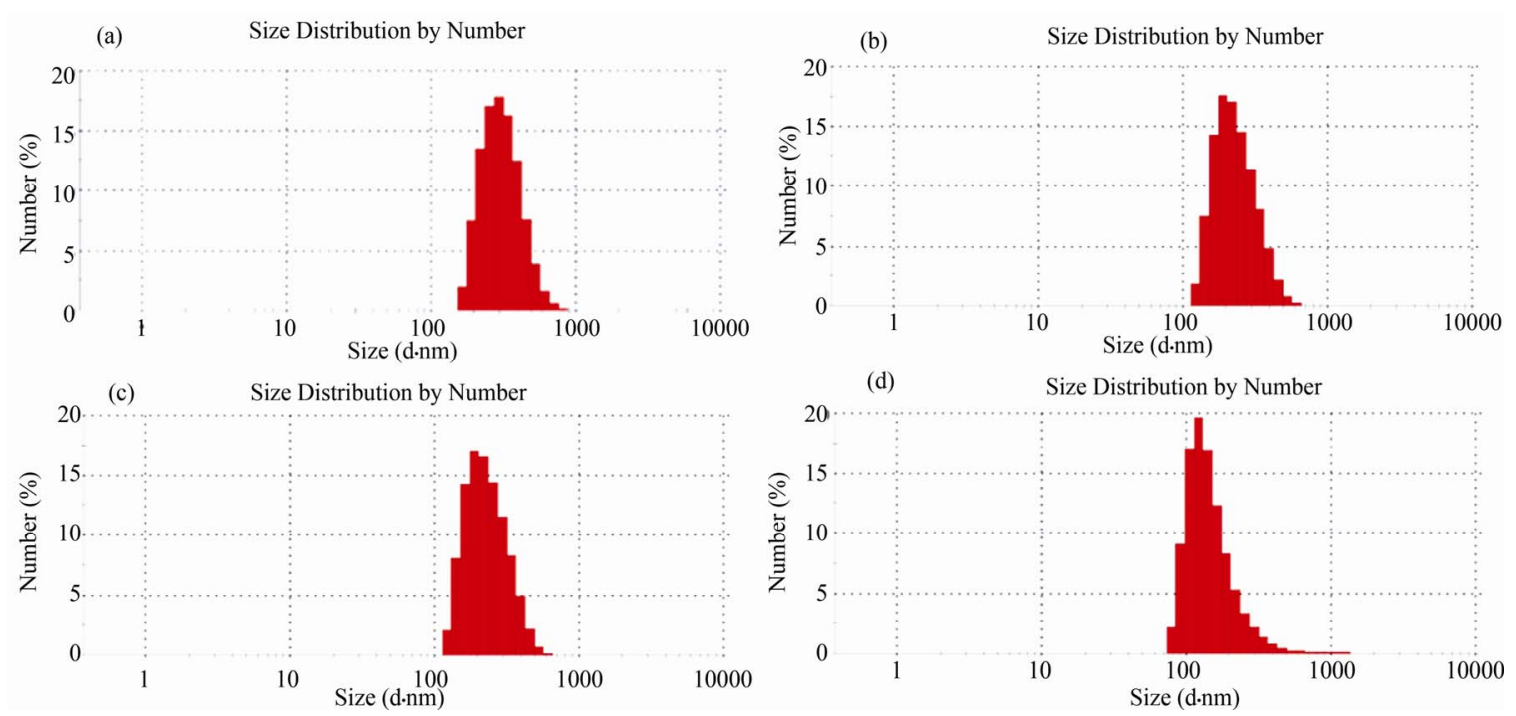

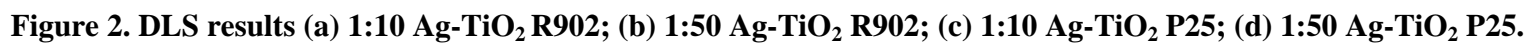




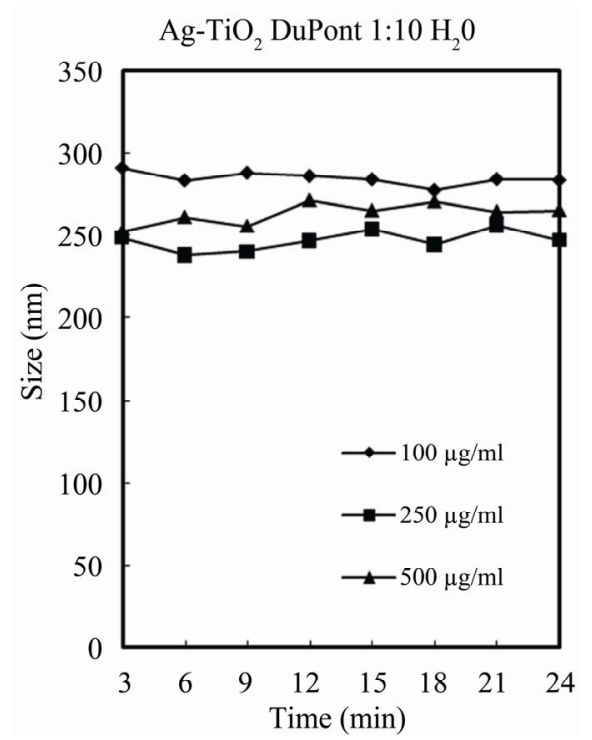

(a)

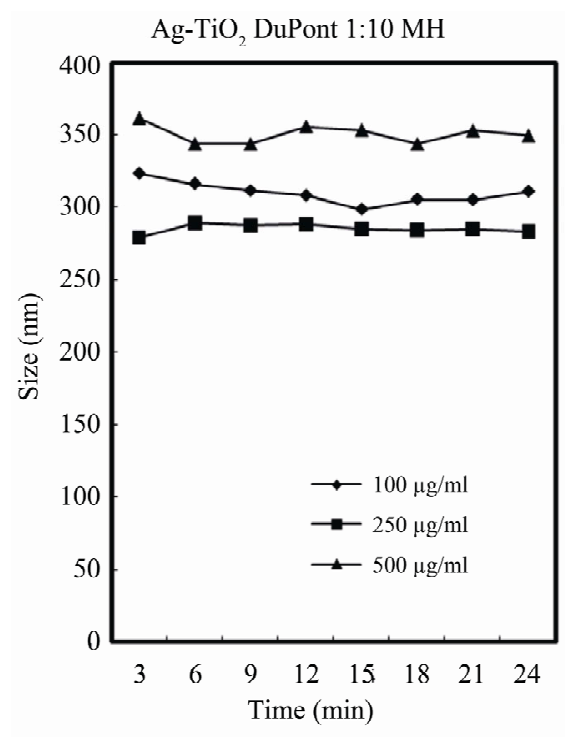

(b)

Figure 3. Temporal evolution of the $\mathrm{Ag}-\mathrm{TiO}_{2}$ DuPont 1:10 composite size (z-average): (a) deionized water; (b) Mueller Hinton Broth.

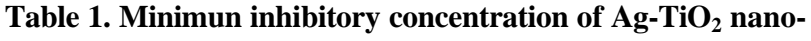
particles against $E$. coli and $E$. faecalis.

\begin{tabular}{|c|c|c|}
\hline Material & $\begin{array}{c}\mathrm{MIC} \\
(\mu \mathrm{g} / \mathrm{mL})\end{array}$ & \\
\hline & $\begin{array}{c}\text { E. coli } \\
\text { (Gram-negative) }\end{array}$ & $\begin{array}{c}\text { E. faecalis } \\
\text { (Gram-positive) }\end{array}$ \\
\hline $\begin{array}{c}\mathrm{Ag}-\mathrm{TiO}_{2} 1: 10 \\
(\mathrm{P} 25)\end{array}$ & $\begin{array}{c}500 \pm 0 \\
500 \pm 0^{a}\end{array}$ & $\begin{array}{c}500 \pm 0 \\
500 \pm 0^{a}\end{array}$ \\
\hline $\begin{array}{l}\mathrm{Ag}-\mathrm{TiO}_{2} 1: 10 \\
(\mathrm{R} 902)\end{array}$ & $\begin{array}{l}500 \pm 0 \\
500 \pm 0^{a}\end{array}$ & $\begin{array}{c}375 \pm 144.3 \\
375 \pm 144.3^{a}\end{array}$ \\
\hline $\begin{array}{c}\mathrm{Ag}-\mathrm{TiO}_{2} 1: 25 \\
(\mathrm{P} 25)\end{array}$ & $\begin{array}{c}500 \pm 0 \\
500 \pm 0^{a}\end{array}$ & $\begin{array}{c}1000 \pm 0 \\
1000 \pm 0^{a}\end{array}$ \\
\hline $\begin{array}{c}\mathrm{Ag}-\mathrm{TiO}_{2} 1: 25 \\
\text { (R902) }\end{array}$ & $\begin{array}{c}500 \pm 0 \\
500 \pm 0^{a}\end{array}$ & $\begin{array}{c}1000 \pm 0 \\
1000 \pm 0^{a}\end{array}$ \\
\hline $\begin{array}{c}\mathrm{Ag}-\mathrm{TiO}_{2} 1: 50 \\
(\mathrm{P} 25)\end{array}$ & $\begin{array}{c}1000 \pm 0 \\
1000 \pm 0^{a}\end{array}$ & $\begin{array}{c}1000 \pm 0 \\
1000 \pm 0^{a}\end{array}$ \\
\hline $\begin{array}{c}\mathrm{Ag}-\mathrm{TiO}_{2} 1: 50 \\
(\mathrm{R} 902)\end{array}$ & $\begin{array}{c}1000 \pm 0 \\
1000 \pm 0^{a}\end{array}$ & $\begin{array}{c}1000 \pm 0 \\
1000 \pm 0^{a}\end{array}$ \\
\hline $\begin{array}{c}\mathrm{TiO}_{2}(\mathrm{P} 25) \\
\mathrm{TiO}_{2}(\mathrm{R} 902)\end{array}$ & $\begin{array}{l}>2000^{b} \\
>2000^{b}\end{array}$ & $\begin{array}{l}>2000^{b} \\
>2000^{b}\end{array}$ \\
\hline
\end{tabular}

\section{Conclusions}

Six different molar ratios $\mathrm{Ag}-\mathrm{TiO}_{2}$ composites were prepared and characterized. We found that $\mathrm{Ag}-\mathrm{TiO}_{2}$ composites increased in size with respect to deionized water when be diluted in Muller-Hinton Broth, but once they grew in size, they remained constant for 24 minutes, and did not affect the MIC for the microorganisms involved. The Ag- $\mathrm{TiO}_{2}$ 1:10 composites showed promising results as an antibacterial agent against E. faecalis Gram-positive and E. coli. Gram-negative bacteria.

\section{Acknowledgements}

M. E. Noriega-Treviño, J. E. Morales-Sánchez and J. M. Guajardo-Pacheco would like to thank CONACYT for grant of scholarships.

\section{REFERENCES}

[1] G. A. Martinez-Castanon, N. Nino-Martinez, J. P. LoyolaRodriguez, N. Patino-Marin, J. R. Martinez-Mendoza and F. Ruiz, "Synthesis of Silver Particles with Different Sizes and Morphologies," Materials Letters, Vol. 63, No. 15, 2009, pp. 1266-1268. doi:10.1016/j.matlet.2009.02.061

[2] A. Panacek, L. Kvitek, R. Prucek, M. Kolar, R. Vecerova, N. Pizurova, V. Sharma, T. Nevecna and R. Zboril, "Silver Colloid Nanoparticles: Synthesis, Characterization, and Their Antibacterial Activity," Journal of Physical Chemistry B, Vol. 110, No. 33, 2006, pp. 16248-16253. doi:10.1021/jp063826h

[3] C. Marambio-Jones and E. M. V. Hoek, "A Review of the Antibacterial Effects of Silver Nanomaterials and Poten- 
tial Implications for Human Health and the Environment," Journal of Nanoparticle Research, Vol. 12, No. 5, 2010, pp. 1531-1551. doi:10.1007/s11051-010-9900-y

[4] O. Choi and Z. Hu, "Size Dependent and Reactive Oxygen Species Related Nanosilver Toxicity to Nitrifying Bacteria," Environmental Science \& Technology, Vol. 42, No. 12, 2008, pp. 4583-4588. doi:10.1021/es703238h

[5] G. A. Martinez-Castanon, N. Nino-Martinez, F. MartinezGutierrez, J. R. Martinez-Mendoza and F. Ruiz, "Synthesis and Antibacterial Activity of Silver Nanoparticles with Different Sizes," Journal of Nanoparticle Research, Vol. 10, No. 8, 2008, pp. 1343-1348. doi:10.1007/s11051-008-9428-6

[6] A. Smetana, K. Klabunde, G. Marchin and C. Sorensen, "Biocidal Activity of Nanocrystalline Silver Powders and Particles," Langmuir, Vol. 24, No. 14, 2008, pp. 74577464. doi:10.1021/1a800091y

[7] S. Pal, Y. Tak and J. Song, "Does the Antibacterial Activity of Silver Nanoparticles Depend on the Shape of the Nanoparticle? A Study of the Gram-Negative Bacterium Escherichia coli," Applied and Environmental Microbiology, Vol. 73, No. 6, 2007, pp. 1712-1720. doi:10.1128/AEM.02218-06

[8] J. R. Morones, J. L. Elechiguerra, A. Camacho, K. Holt, J. B. Kouri, J. T. Ramirez and M. J. Yacaman, "The Bactericidal Effect of Silver Nanoparticles," Nanotechnology, Vol. 16, No. 10, 2005, pp. 2346-2353. doi:10.1088/0957-4484/16/10/059

[9] L. Kvitek, A. Panacek, J. Soukupova, M. Kolar, R. Vecerova, R. Prucek, M. Holecova and R. Zboril, "Effect of Surfactants and Polymers on Stability and Antibacterial Activity of Silver Nanoparticles (NPs)," Journal of Physical Chemistry C, Vol. 112, No. 15, 2008, pp. 5825-5834. doi:10.1021/jp711616v

[10] S. Shrivastava, T. Bera, A. Roy, G. Singh, P. Ramachandrarao and D. Dash, "Characterization of Enhanced Antibacterial Effects of Novel Silver Nanoparticles," Nanotechnology, Vol. 18, No. 22, 2007, pp. 225103-225111. doi:10.1088/0957-4484/18/22/225103

[11] K. Page, R. G. Palgrave, I. P. Parkin, M. Wilson, S. L. P. Savin and A. V. Chadwick, "Titania and Silver-Titania Composite Films on Glass-Potent Antimicrobial Coatings," Journal of Materials Chemistry, Vol. 17, No. 35, 2007, pp. 95-104. doi:10.1039/b611740f

[12] N. Nino-Martinez, G. A. Martinez-Castanon, A. Aragon-
Pina, F. Martinez-Gutierrez, J. R. Martinez-Mendoza and F. Ruiz, "Characterization of Silver Nanoparticles Synthesized on Titanium Dioxide Fine Particles," Nanotechnology, Vol. 19, No. 6, 2008, Article ID: 065711. doi:10.1088/0957-4484/19/6/065711

[13] G. Fu, P. S. Vary and C. Lin, "Anatase $\mathrm{TiO}_{2}$ Nanocomposites for Antimicrobial Coatings," Journal of Physical Chemistry B, Vol. 109, No. 18, 2005, pp. 8889-8898. doi:10.1021/jp0502196

[14] J. Thiel, L. Pakstis, S. Buzby, M. Raffi, C. Ni, D. J. Pochan and S. I. Shah, "Antibacterial Properties of SilverDoped Titania," Small, Vol. 3, No. 5, 2007, pp. 799-803. doi:10.1002/smll.200600481

[15] M. Yeo and M. Kang, "Effects of Nanometer Sized Silver Materials on Biological Toxicity during Zebrafish Embryogenesis," Bulletin of the Korean Chemical Society, Vol. 29, No. 6, 2008, pp. 1179-1184. doi:10.5012/bkcs.2008.29.6.1179

[16] P. Bihari, M. Vippola, S. Schultes, M. Praetner, A. Khandoga, C. A. Reichel, C. Coester T. Tuomi, M. Rehberg and F. Krombach, "Optimized Dispersion of Nanoparticles for Biological in Vitro and in Vivo Studies," Particle and Fibre Toxicology, Vol. 5, No. 14, 2008, pp. 1-14.

[17] R. MacCuspie, "Colloidal Stability of Silver Nanoparticles in Biologically Relevant Conditions," Journal of Nanoparticle Research, Vol. 13, No. 7, 2011, pp. 28932908. doi:10.1007/s11051-010-0178-x

[18] S. Kitller, G. Greulich, J. S. Gebauer, J. Diendorf, L. Treuel, L. Ruiz, J. M. G. Calbet, M. Vallet-Regi, R. Zellner, M. Köller and M. Epple, "The Infuence of Proteins on the Dispersability and Cell-Biollogical Activity of Silver Nanoparticles," Journal of Materials Chemistry, Vol. 20, No. 3, 2010, pp. 512-518. doi:10.1039/b914875b

[19] Z. Ji, X. Jin, S. George, T. Xia, H. Meng, X. Wang, E. Suarez, H. Zhang, E. M. H. Hoek, H. Godwin, A. E. Nel and J. I. Zink, "Dispersion and Stability Optimization of $\mathrm{TiO}_{2}$. Nanoparticles in Cell Culture Media," Environmental Science \& Technology, Vol. 44, No. 19, 2010, pp. 7309-7314. doi:10.1021/es100417s

[20] I. Lynch, A. Salvati and K. A. Dawson, "Protein-Nanoparticle Interactions. What Does the Cell See?" Nature Nanotechnology, Vol. 4, No. 9, 2009, pp. 546-547. doi:10.1038/nnano.2009.248 